\title{
'Neutrality', Muslimness and the whiteness of RE professionalism
}

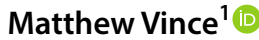

Accepted: 9 September 2020 / Published online: 19 September 2020

(c) The Author(s) 2020

\begin{abstract}
There has been longstanding criticism of the whiteness of the professional discourses in teaching. Bariso (Race Ethn Educ 4(2):167-184, https://doi.org/10.1080/713693054, 2001) writes that where whiteness is constructed as being professional then blackness is constructed as unprofessional, in turn excluding blackness from the construction of the teacher. Similarly, Bhopal (Br J Educ Stud, 63(2):197-211, https://doi.org/10.1080/00071 $005.2015 .1005045,2015)$ argues that this presents a clash between embodying blackness and embodying the teacher. With the turn to research surrounding Muslim teachers, attributes of Muslimness have also been shown to be a source of marginalisation within school contexts (Shah in Education, leadership and Islam: theories, discourses and practices from an Islamic perspective, Routledge, London, 2016). Some scholarship has reflected on issues surrounding embodiment and 'body-works' of RE teaching's professional discourses (Bryan and Revell in Br J Educ Stud 59(4):403-419, https://doi.org/10.1080/00071 005.2011.602328, 2011; Everington in $\mathrm{Br} \mathrm{J}$ Religious Educ 36(2):155-173, https:// doi.org/10.1080/01416200.2013.820169, 2014; Vince in J Beliefs Values, https://doi. org/10.1080/13617672.2019.1686732019, 2019). Such empirical studies have shown that embodying faith is perceived to be at odds with notions of RE teacher professionalism, particularly around notions of 'neutrality' (Everington in Br J Relig Educ, 38(2):177-188, https://doi.org/10.1080/01416200.2016.1139892, 2016). Despite the concept of 'neutrality' being increasingly criticised (Franken and Loobuyck in Br J Relig Educ, 39(1):1-6, https://doi.org/10.1080/01416200.2016.1218219, 2017), embodying 'neutrality' remains an important commitment. This has clear implications for (hyper)visible religious bodies (Jeldtoft, in: Dessing et al. (eds) Everyday Lived Islam in Europe, Routledge, London, 2016). Accordingly, in this paper I explore how 'Muslim RE teachers' manage their identities in relation to 'being neutral'. For these teachers, 'becoming neutral' was the formative part of becoming an RE teacher. However, this was particularly challenging due to the hypervisibility of their Muslimness, particularly for female Muslim teachers. These challenges are then framed as an issue of whiteness, disproportionally affecting those who do not fit the white teacher norm. I end on arguing that there is a pressing need to change how 'neutrality' is understood.
\end{abstract}

Matthew Vince

vincem@cardiff.ac.uk

1 Centre for the Study of Islam in the UK, Cardiff University, Cardiff, Wales, UK 
Keywords Religious education · Professionalism · Islam · Muslims

\section{Introduction}

There has been longstanding criticism of the whiteness of the professional discourses in teaching (Bariso 2001; Benn 2002; Benn et al. 2011; Bhopal 2015; Shah and Shaikh 2010). Bhopal (2015, p. 204) draws attention to the embodiment of race as a site of conflict with teacher professionalism:

For many respondents, their 'presentation of self' (Goffman 1959) manifested itself in their clothes and dress, but also in their professionalism towards pupils and their colleagues. The 'presentation of self' had a significant impact on how they were judged and the extent to which they were able to ensure their acceptance within the school space.

Here, embodying whiteness is constructed as being professional, whilst embodying blackness becomes seen as unprofessional. This presents a clash between embodying blackness and embodying the teacher (Bhopal 2015, p. 204). As such, white notions of teacher professionalism serve to exclude blackness from its construction (see also Bariso 2001). Thus, considering race and teacher professionalism introduces an embodied aspect to the experience of BAME teachers.

Embodying professional discourses has also presented a challenge within discussions of RE teaching, particularly around the aspect of 'neutrality'. Reflecting RE's commitment to a non-confessional, phenomenological approach to religion, the notion of the RE teacher has become enshrined in ideas of 'neutrality' and 'objectivity' (Franken and Loobuyck 2017). Although a contested concept, 'neutrality' broadly entails 'concealment of any personal commitment on the teacher's part' in the RE classroom (Jackson and Everington 2017, p. 10). Often these concerns around 'being neutral' reflect underlying worries with the RE teacher's capacity to influence or indoctrinate pupils, given their authority and potential positions as role models (Everington 2016). This would also compromise RE's non-confessional orientation (Religious Education Council 2013). Therefore, notions of RE teachers' professionalism has become bound up with a teacher's capacity to embody the 'neutral RE teacher', meaning their ability to 'conceal' their faith.

Aside from the theoretical debates surrounding the concept of 'neutrality', there is a small body of literature that has uncovered the 'body-work' that religious individuals engage in to 'conceal' their faith in RE teaching in order to be 'neutral'. These empirical studies have shown that embodying faith was perceived to be at odds with participants' understandings of RE teacher professionalism (Everington 2016, p. 18). In Bryan and Revell's (2011, p. 413) study of 160 RE Initial Teacher Trainees (ITTs), Christian RE ITTs felt 'that an explicit articulation of their faith was inappropriate within the performative context of school'. As a result, 'many Christian students experienced the perceived pressure to hide or minimise their religious commitment in public in different ways' to 'deny or minimise the impact of their faith on their ideas about teaching' (2011, pp. 414-415). Similarly, Everington (2016, p. 160) notes that the religious participants in her study 'feared that they would be viewed as pushing a religious message or even attempting to convert pupils'. The need to stress that they were 'not there to indoctrinate' is also noted by Miller and McKenna (2011) as an almost automatic response, whilst Sikes and Everington (2003) draw attention to a pervasive stereotype from pupils of RE teachers as agents of indoctrination. 
In response, changing their bodies was a way to show their resistance to these stereotypes, such as by dying their hair unusual colours or through certain styles of dress (Sikes and Everington 2004). In contrast, non-religious RE ITT's reported feeling much more open to incorporating their worldview in the classroom. Such tensions are exacerbated by a 'policy grey area' around including an individual's faith in their role as the RE teacher (Everington 2014). Consequently, being visibly religious seems to be at odds with RE teachers' understanding and embodiment of their professional role.

Yet, despite there being clear implications of embodiment in the act of RE teaching, there has been little engagement with issues of race, embodiment and whiteness within such discussions of the professional discourses of RE teaching. With the turn to research surrounding 'Muslim teachers', attributes of Muslimness ${ }^{1}$ have also been shown to be a source of marginalisation within the school space (Shah and Shaikh 2010). Everington's $(2014,2015)$ work in particular has begun to highlight the way the visibility of 'Muslim RE teachers' affects their pedagogy through their use of 'personal life knowledge', as a way to bridge the ontological gap between their personal faith identity and their professional teacher self. Similarly, I have previously written about how 'Muslim RE teachers' bridge the personal-professional gap in their understanding of themselves as teachers (Vince 2019). This is now compounded by the professional discourse of the 'neutral, objective RE teacher', and the recent intrusion of Prevent, and its implications for these hypervisible religious actors (Farrell 2016).

Accordingly, in this paper I explore how 'Muslim RE teachers'2 managed the embodiment of their identities in relation to the RE's professional discourses, specifically around 'being neutral'. Although 'being neutral' remained a vital part of the participants' identity as RE teachers, this was challenging due to the hypervisibility of their Muslimness (Jeldtoft 2016). Considering these challenges through the frame of whiteness, I argue that the current conception of professionalism as 'neutral' disproportionally affects those who do not fit the white teacher norm. I end on arguing that there is a pressing need to work to change how 'neutrality' is understood, leaning toward a preference toward 'impartiality' (Jackson and Everington 2017).

\section{Methodology}

This paper is based on my qualitative doctoral research conducted from 2015 to 2018 . The project sought to explore how the participants' personal faith identity and professional teacher identity intersected in their role as RE teachers. A narrative approach to teacher identity (Connelly and Clandinin 1999) was employed alongside 'everyday' and 'lived' forms of religion (Ammerman 2014; Bender et al. 2013) to focus on how the participants constructed and 'lived' these identities within their school contexts. The locus of these two approaches was the body, as a place where the personal and professional became entwined. As Estola and Elbaz-Luwisch (2003) summarise, the teacher's body is the tool 'of the language of practice' and so is 'simultaneously concrete and culturally bound' by their other

\footnotetext{
1 The (often) visible 'religious practices, symbols and rituals' that underpin Muslim identity construction (Shah 2016).

2 'Muslim RE teachers' are presented in quotation marks throughout to reflect its contested nature (see Vince 2019).
} 
identities. Hence, the body and embodiment were essential aspects of the participants' narratives.

\section{Methods}

21 'Muslim RE teachers' participated in the study. This was not intended to be a representative sample as there is currently no information about the religious identification of RE teachers in the UK. However, the sample represents one of the largest qualitive studies of 'minority ethnic and religious' RE teachers to date.

The research specified only that participants self-identify as Muslim, recognising the openness of this identification, and were also the holder of Qualified Teacher Status (QTS) and were working as, or had worked as, a Secondary RE teacher as identified by job, or was the principal subject that they taught. The participants are from a variety of denominations, with 14 Sunni Muslims, two Shia Muslims, two Sufi Muslims, one Ahmedi Muslim, and two who described themselves as 'cultural' and 'political' Muslims. They were primarily female $(n=15)$ and the majority spoke of wearing visible Muslim dress during their teaching, specifically the hijab. The sample were predominantly of Asian ethnicity $(n=20)$, with one white male Muslim convert. Participants were recruited across England, located in the North West, Midlands, South East and South West. From this sample, intersections of race, gender, and denominational identifications are present within the participants' narratives, along with their various notions of being an 'RE teacher'.

Two data collection methods were used. Semi-structured interviews were used as the primary data collection method. Interviews were designed to elicit participants' narratives of their personal faith identity, professional identity, and how these two came together and were experienced in their day-to-day work. The data reflects 21 interviews overall, one per participant, with each ranging between one to three hours in length. All the interviews were recorded on a Dictaphone and transcribed verbatim.

This data was enriched by three participant shadows. Shadowing has been described as 'observation on the move', where the researcher follows a target participant observing their work (Czarniawska 2014). As shadowing allows the researcher to 'share the experiences' with their participants (2011), this data was used to enrich the interview data by allowing me as researcher to experience how the participants' identities played out in the classroom. Three participants: Mrs Khan, Miss Aziz and Mr Jones, were shadowed for 2 to 3 days a week, totalling 24 days of observation conducted over ten weeks during the Spring and Summer terms of 2017. Observations were recorded in a fieldwork journal and were then transcribed.

\section{Ethics and positionality}

The doctoral research was ethically approved by Cardiff University's School of Social Sciences Ethics Committee, and designed according to the British Educational Research Association (2018) Ethical Guidelines for Educational Research and Cardiff University's School of Social Sciences Ethics Committee guidelines. Whilst all names and places have been changed to protect anonymity, they continue to reflect the participants' denominational identification, gender and ethnicity in an attempt to avoid erasing their identities (Guenther 2009). 
As a white, male, non-Muslim researcher and 'outside' the community, my position has given me a limited understanding of the participants' experiences. Scholars have noted a 'general sense of mistrust' toward 'outsider' researchers investigating Muslim communities (Bolognani 2007, 2005; Spalek 2005). In the research I used my own experience of RE teaching from which to reflect on the experience of the participants. As such, I have leaned toward the professional aspect within the analysis, eschewing considerations of what constitutes Muslimness. In the paper I have attempted to attend to the limitations of my position by giving space to the voice of the participants, using extended quotations with citations from the data collection. Although I cannot capture the 'secret knowledges' of marginalised groups (Spalek 2005, p. 414), 'giving voice' has been widely used in feminist research (McDowell 2016).

\section{Findings}

\section{1 'Neutrality' as whiteness}

As I have noted elsewhere (Vince 2019), participants' construction of their teacher identities centred on the notion of 'being neutral'. In the classroom, their sense of 'neutrality' intersected with their visibility as Muslims. Visible signs of Muslimness meant that the participants were constructed as Muslims in their role, complicating their capacity to conceal their personal faith identity. For example, Mr Chowdhury spoke of his experience of being the only "brown person" in his school and local community:

Because I've got nothing to hide. I can't un-brown myself. I'm going to be brown, so I'm evidently somebody who's different. And then, well, you know, my wife... she wears a headscarf. And, you know, they're obviously going to see my wife, because, you know, [area]'s not a very big place. And it's just everybody's going to come to know that that's [my] wife (Interview 18, 45:10-49:03).

Here, Mr Chowdhury's ethnicity made it "evident" that he was a Muslim, and hence the pupils related to him as such. Here the whiteness of his context drew out his personal identity in his teaching and so problematised his capacity to conceal his Muslim identity-he cannot "un-brown" himself. This shaped his subsequent teaching practice because his faith was necessarily brought into the classroom by his pupils.

The process of racialisation was also distinctly gendered, with the hijab at the centre of these concerns. Those who wore the hijab spoke of being "obviously" Muslim at the front of the classroom. So, by embodying their faith visibly, they necessarily brought this with them into their teacher identity. As Miss Loonat explained, her identity as an "in your face Muslim" by wearing the hijab meant she had to share her identity:

Erm... I think you'd have to 'cuz like [other teacher] is like an atheist but he doesn't say that he's an atheist, but I'm kinda in your face I'm a Muslim. So, you have to like - and like I know part of the role is by you not telling the kids your religion, y'know indoctrinating them ' $n$ ' all that, but you kinda can't hide it with being a Muslim (Interview 10.2, 4:00-6:53).

The visibility of the hijab problematised the participants' capacity to conceal their Muslim identity and 'be neutral'. The juxtaposition with the atheist teacher here particularly draws attention to the whiteness of the discourse of 'neutrality' itself. In a way, 'neutrality' is the 
privilege of the teacher who can hide their personal faith identity-something that was not seen as possible for Miss Loonat. Wearing the hijab therefore potentially became a site of conflict between embodying their faith and being professional. Potential tensions with notions of professionalism were a constant theme in the discussion with the participants who wore the hijab. These tensions were especially felt during the moments when they first decided to wear the hijab at work.

These tensions surrounding wearing the hijab as RE teachers often compounded wider social tensions with staff and pupils. Deliberations over whether to wear, or keep wearing, the hijab, were a feature of some of these participants' narratives, who had experienced social isolation as a result. These decisions were often significant turning points in these participants' narratives, symbolising an evolution in their understanding of themselves as teachers and corresponding with a shift in their understanding of 'neutrality' (discussed in the next section). Similar tensions have also been highlighted in scholarship previously (Benn 2003; Benn et al. 2011). For example, Benn (2003, p. 143) highlights that;

Usually, the women found themselves to be the only Muslim teacher in the school, and, again, those who wore the hijab/Muslim dress found this distanced them from colleagues, for example from being included easily in staff-room conversation, sometimes feeling alienated by the culturally specific topics of conversation that arose.

However, notions of 'neutrality' in the RE role could come together to heighten these feelings of social isolation and alienation, evoked in concerns surrounding 'indoctrination'. Although many of the participants saw themselves as role-models, particularly for female Muslim pupils, there was occasionally a sense of wariness in these discussions. For example, Mrs Iqbal remarked that;

I think... it's interesting because I was there for quite a while as the only Asian teacher, but there's quite a few now, and there's another science teacher that wears the hijab. But I think that some of the parents, especially when you're teaching RE, they think that you are going to convert the kids sometimes (Interview 1, 21:4221:51).

As such, there is evidence of a unique intersection between the prevalent understandings of RE teacher professionalism, centred around notions of 'neutrality', that heightens the perceived alterity of Muslimness in the 'body-work' of the RE teacher.

Engaging in religious practice also extended to potentially compromising one's professional identity, as in the case of the "outing" of Mr Jones. As a white male Muslim convert working as an RE teacher in a predominantly white environment, Mr Jones had tried to conceal his Muslim identity completely from other staff and pupils in his school. He had decided to hide his Muslim identity so that others would "get to know him" as a person before him as a Muslim (Interview 6, 33:38-36:20). However, he spoke of being "outed" as a Muslim:

Well I mean I outed myself to my [Head of Department] just because I needed to pray quite a lot, and he - but for quite a long time I didn't y'know. I think I was caught praying behind the bike shed - not the bike shed it was actually a PE shed - by one of the PE staff. So y'know it was a kind of an open secret. But I felt very wary of kind of saying that I was Muslim. Partly sort of for personal safety - that overblows it, nothing physical - feeling physically unsafe - but knowing that - I think that's it knowing that certain assumptions would be made about me and so I wanted to establish myself in the school (Interview 6, 39:06-44:23). 
After his "outing", Mr Jones spoke of being reduced to his Muslim identity by other staff, much to his frustration, as he recalled in the following incident:

They're seeing me through that lens. There was a house singing competition where these teenagers - pre-16 teenagers, were singing the song 'Timber'. The lyrics are just extraordinary - basically it is about sexual violence really... I went to the deputy head in charge and said this is completely outrageous, and apparently when it went to [Senior Leadership Team] the head's reaction was wrong - "Oh we're not having any religious considerations here". So you see everything - I can never escape being a Muslim - I'm never just a teacher... It's enormously frustrating. Which is why I think I would play it differently in a new school, because again even if everybody knows - I dunno maybe there's just no escaping it? (Interview 6, 44:23-48:30).

Mr Jones's subsequent construction as Muslim caused tensions with other staff with regards to his professionalism. His perspective, now always reduced to his personal faith, had seemingly compromised his capacity to offer professional perspectives. Again, this compromise was understood to be exacerbated by his position as an RE teacher in his school.

Other participants remarked on the struggle to remain 'neutral' during classroom discussions with pupils. Being 'obviously Muslim', it was common for the participants to be asked by pupils what they thought about the topic at hand. With these questions, Miss Loonat was especially cautious when answering such questions:

I answer them like as much as I can - so like y'know to the point where it is just a generic... I'd never make sure that I'm by myself up there, like there's always - "Oh you think so too?", y'know like get their opinions first, or sometimes like with some questions you go "You're not supposed to know that about me, that's a personal question" - "Yeah but you've asked us Miss", but you're the one who's gonna be answering not me (Interview 10.2, 4:00-6:03).

Miss Memon, an NQT, faced considerable scrutiny from her Muslim pupils who knew her faith:

I think, like for instance during the lesson, like I said before, some students will say to me like during the lesson "Oh Miss are you a Muslim?" And I would be like yes and that's it... But the boundaries will lie when they start asking me during the lesson random things like "Oh Miss do you believe in this about our religion?". "Oh Miss do you agree with this about our religion?" (Interview 15, 50:41-1:04:01).

In these accounts the questioning of pupils invokes their personal faith identity in the discussion, revealing that the pupils are relating with the participants as a Muslim RE teacher. In these moments, this was seen to erode their sense of 'being neutral' as their faith was visibly part of their teacher identity. As can also be seen in the accounts, this led to uncomfortable tensions on the limits of what is professional: what they could and should share.

These accounts draw attention to the embodiment of race, religion, and gender, and how they intersect with the notion of neutrality, highlighting the whiteness of the concept. Being visibly Muslim re-positioned the participants from 'being neutral' to 'being a Muslim' in their relationships with other pupils and staff. The hypervisiblity of their Muslimness, be that through their ethnicity, certain forms of dress, and engaging in certain practices, meant that being 'neutral' was much more difficult to sustain within their school contexts. In response, the participants had adopted an array of different coping strategies to manage professional tensions surrounding this re-positioning. 


\subsection{Shifting ideas of 'neutrality' in concept and practice}

Participants expressed a shift in understanding over the course of their careers of how they understood 'neutrality': from 'concealment' to 'impartiality'. For many of the participants, it soon became clear that staff and pupils had built relationships with them as Muslim RE teachers. As such, it was almost due to a pragmatic necessity that they shifted how they understood their professional duty to 'being neutral'. Mrs Khan, a Head of Department of 10 + years of teaching, exemplified this shift in her reflection on her teacher identity:

I just have sort of become a bit more used to what I am. Because of just sort of moulded into it and I've become it. But I think if I was in a sort of mainstream, non-Muslim [majority] school, it would be something that I think I would challenge myself with and I would question, maybe because it's quite difficult to connect like with the problems I had before (Interview 16, 13:04-23:49).

Being a Muslim in the classroom was something that Mrs Khan had 'become more used to'. Working in a school with a large number of Muslim pupils, hiding her Muslim identity was an aspect of the role that she found difficult to maintain, especially given that the pupils were aware of her faith. Similarly, Mr Chowdhury explained how he came to use his 'personal life knowledge' in the classroom to ontologically bridge with his white pupils:

Well, you know, I made it very clear, you see, from when... When I got my feet in, you know, I became more established, you know, I would share personal stories with students. I was very explicit with my experiences...To make [RE] real, I had a huge advantage of being a brown Muslim who had experienced it, than just a normal, white RE teacher who is referring to examples (Interview 18, 27:17-37:32).

Here Mr Chowdhury had configured his experience of being a Muslim in a predominantly white area as a pedagogical resource in the classroom. By sharing powerful personal stories, he was able to bring in his faith identity to bridge the ontological gap between himself and his white students, evoking in them the impact of racism that he had experienced. This also "made it real" for them, expressing his use of 'personal life knowledge' pedagogically, enriching his teaching about racism from real experience. As such, participants, especially those who had been teaching for several years, seemed to have moved to including their own faith in the classroom as regular teaching practice. Specifically, these findings echo the use of 'personal life knowledge' found by Everington $(2014,2015)$ amongst trainee RE teachers from 'minority ethnic and religious' backgrounds.

Code-switching was also an integral part of the participants' pedagogy, used to signal when they were talking from a neutral perspective and when they were talking from a personal faith perspective. This involved paying close attention to their 'teacher talk', centring on the use of "Muslim" to signal a neutral position and "we" or "I" for a personal position. The development of this code was a formative moment in the participants' careers:

The fact that, since I started teaching, I always knew I was teaching their religion, like in the example, you say, a Christian would say, a Muslim would say? That's the way I will teach (Miss Mahmood, Interview 21, 49:20-53:01).

I remember when I was doing my PGCE... And I remember my mentor she said to me, "you know what you said 'we', as in 'we do that', as in Muslim", and it must 
of been a slip of the tongue, and I was new to teaching, and that just stuck in my head - I said I'm NEVER ever going to do that again (Miss Ahmed, Interview 3, 42:00-43:52).

The code itself: "Muslim" or "I" is a clear signal of the different underlying commitments of their 'teacher talk' in that given moment. In this way, code-switching allowed the participants to "be" different people at various points of their teaching, and so to present various positions in class. Through the utterance of "Muslim", the participant was portraying a view of Muslims as constructed from the 'professional knowledge landscape' of the curriculum content. The use of the factual term is symbolic of their distancing of themselves as neutral RE teachers from their personal faith repertoire of meaning-making. In contrast, the switch to "I" invokes the faith repertoire, bringing with it the expectations to "be Muslim" in that moment.

As such, the use of this code-switching was a linguistic way of regaining control of the expressions of their body. Code-switching was often employed in response to pupils' questions ("Miss, what do you think?") which caused a shift from the "neutral' to the personal. This was significant given the participants' visibility as Muslims, affording them some control in the social milieu of the classroom as way to maintain their alignment with their 'neutral' RE teacher identity.

It was also used to protect their Muslim identity in discussions that they may have disagreed with from a faith perspective. For example, Miss Meer stated that:

Even when I teach Islam, I teach it as, this is what Muslims believe, this is what they believe, not this is what I believe, because there are some of those beliefs, as a Mus$\mathrm{lim}$, that I don't agree with even though I know, within the community, I wouldn't really be praised for saying that (Interview 17, 1:04:04-1:07:38).

This reveals an interesting facet of the concept of 'neutrality' that has otherwise been overlooked: as an ontological space in which the participants could retreat to in order to maintain the integrity of their personal faith. The wider literature has been highly critical of the 'secular' shape that the discourse of neutrality forms (Bryan 2012; Bryan and Revell 2011; Cooling 2010; Copley 2005). But here, the ability to maintain 'neutrality' when discussion turned uncomfortably with the participants' own faith afforded them the capacity not to be bound by these obligations in that moment.

\section{Discussion}

The present analysis has offered a new perspective on notions of RE professionalism in terms of its intersection with visibility and race. 'Neutrality', understood as the concealment of one's faith identity, was complicated by the hypervisibility of the participants' Muslimness, whether this be through their ethnicity, forms of dress or religious practice. The embodiment of themselves as Muslims therefore complicated their capacity to achieve the professional norm of 'neutrality' by eliciting their faith within their school contexts. This, in turn, reveals the whiteness of the concept of 'neutrality' itself: specifically that one's faith is something that is not visible. This is further reinforced by the perception that 'neutrality' was easier to achieve by white atheist or Christian teachers.

These professional tensions manifest in various ways, that reflects the wider BAME teacher literature. The 'policy grey area' surrounding sharing one's beliefs and opinions, as noted by Everington (2014), meant that moments where their Muslim identities were often 
invoked were approached cautiously, such as in classroom discussions. Signs of Muslimness also could reduce the participants' agency to their religious identity, as in the case of Mr Jones. As such, 'Muslim RE teachers' are seemingly faced with a choice between being a 'good Muslim' or a 'good teacher' (Benn 2003), having to potentially compromise the integrity of their faith in order to be seen as professional in the RE classroom.

Changing understandings of 'neutrality' and the adoption of various coping strategies support these observations further, suggesting that these teachers are developing ad hoc ways of managing these professional tensions. Osler (1997) argues that the use of such 'survival strategies' are employed by BAME teachers to 'survive' in their school contexts. The main strategy that seemed to be employed was a shifting understanding of 'neutrality' itself: from concealment to a more impartial mode of 'neutrality'. For Jackson and Everington (2017, p. 10), impartial teachers of RE:

are prepared to consider rival conclusions as well as those to which they are personally attached and have the skill and sensitivity to know how and when to contain their personal commitments and how to present material from a religion/religious tradition from the point of view of an adherent. This professional skill does not require teachers to disguise their own position.

This understanding reflects the shift that the participants made during their teaching careers. In many ways this was a pragmatic necessity; as Mr Chowdhury put, they were 'evidently' Muslim and so were related to as such in the classroom. Thus, their faith was already included in the social milieu of the classroom, precluding any notion of complete concealment. Being impartial enabled the participants to recognise their faith in the classroom, whilst being aware that it was one voice amongst many. Just as Jackson and Everington (2017) suggest that this is a professional skill that develops over time, so too did the participants express becoming increasingly more comfortable using their experiences. Strategies of code-switching and the extensive use of 'personal life knowledge' are pedagogical manifestations of this shift in understanding, ways in which the participants negotiated the 'grey area' between their faith and their professional selves. However, none of the participants reported learning about these skills: they were strategies that they had all developed individually and ad hoc by reflecting on their experience.

However, there were still moments where the participants had to engage in the 'concealment' of their personal faith. This did not mean that the participants saw themselves as unprofessional, or unable to be professional. Nor did most of the participants advocate anything other than non-confessional RE. In fact, in certain instances, as exemplified by Miss Loonat, being able to retreat to 'neutrality' was a way in which the participants could maintain a boundary between their personal and professional selves. The concern amongst the participants, however, was their awareness that they had to engage in different practices that were distinct from wider notions of professionalism within RE teaching.

\section{Concluding remarks}

It is striking how little the bodies of RE teachers are considered in wider pedagogical and professional debates, and there is a pressing need for more empirical research in RE about $\mathrm{RE}$ teachers themselves. Specifically, further empirical research is needed that explores the experiences of 'minority ethnic and religious' RE teachers, in terms of the pragmatic realities of their school contexts. 
Reflecting on the findings in this study, I argue that there is also a need to revise the professional discourses of 'neutrality' to the more impartial mode as outlined by Jackson and Everington (2017). Despite 'neutrality' being an 'impossible aim' in the scholarly literature (Franken and Loobuyck 2017), it is clear that it remains a pervasive concept in many RE teachers' understanding of their professional self. Such professional discourses exclude certain bodies; those that are hypervisible in our current social and political context. As opposed to 'concealment', RE teachers should be encouraged to include themselves in the classroom as 'one voice amongst many'. 'Impartiality' allows for expressions of faith whilst also maintaining a 'neutral' space that RE teachers can retreat to. Doing so will begin to allow for diverse bodies and voices within the RE space.

The strategies explored in this paper could be used as a starting point to support the training and on-going development of 'Muslim RE teachers' and religiously committed RE teachers of other faiths. The use of 'personal life knowledge' (Everington 2012, 2014, 2015) seems to be an especially useful way of incorporating one's faith in the classroom as a resource, blending both professional practice and personal experience. The fact that the strategies so central to RE teaching were developed individually and ad hoc is a statement of the shortcomings of current CPD and ITT. Furthermore, developing an understanding of 'neutrality' as 'impartiality' was fundamental to the participants' professional development. Making 'Muslim Initial Teacher Trainees' and other teachers aware of these narratives, and the strategies they employed in the classroom, could therefore provide significant support.

Funding This study was funded by the Jameel Scholarship Programme.

\section{Compliance with ethical standards}

Conflict of interest The authors declare that they have no conflict of interest.

Open Access This article is licensed under a Creative Commons Attribution 4.0 International License, which permits use, sharing, adaptation, distribution and reproduction in any medium or format, as long as you give appropriate credit to the original author(s) and the source, provide a link to the Creative Commons licence, and indicate if changes were made. The images or other third party material in this article are included in the article's Creative Commons licence, unless indicated otherwise in a credit line to the material. If material is not included in the article's Creative Commons licence and your intended use is not permitted by statutory regulation or exceeds the permitted use, you will need to obtain permission directly from the copyright holder. To view a copy of this licence, visit http://creativecommons.org/licenses/by/4.0/.

\section{References}

Ammerman, N. (2014). Finding religion in everyday life. Sociology of Religion, 75(2), 189-207. https://doi. org/10.1093/socrel/sru013.

Bariso, E. (2001). Code of professional practice at stake? Race, representation and professionalism in british education. Race Ethnicity and Education, 4(2), 167-184. https://doi.org/10.1080/713693054.

Bender, C., Cadge, W., Levitt, P., \& Smilde, D. (Eds.). (2013). Religion on the edge: De-centering and recentering the sociology of religion. Oxford: Oxford University Press.

Benn, T. (2002). Muslim women in teacher training: Issues of gender, 'race'and religion. In D. Penney (Ed.), Gender and physical education: Contemporany issues and future directions (pp. 57-79). London: Routledge. 
Benn, T. (2003). Muslim women talking: Experiences of their early teaching careers. In T. Benn \& H. Jawad (Eds.), Muslim women in the United Kingdom and beyond: Experiences and images. Brill: Leiden.

Benn, T., Dagkas, S., \& Jawad, H. (2011). Embodied faith: Islam, religious freedom and educational practices in physical education. Sport, Education and Society, 16(1), 17-34. https://doi.org/10.1080/13573 322.2011.531959.

Bhopal, K. (2015). Race, identity and support in initial teacher training. British Journal of Educational Studies, 63(2), 197-211. https://doi.org/10.1080/00071005.2015.1005045.

Bolognani, M. (2007). Islam, ethnography and politics: Methodological issues in researching amongst West Yorkshire Pakistanis in 2005. International Journal of Social Research Methodology, 10(4), 279-293. https://doi.org/10.1080/13645570701546570.

British Educational Research Association. (2018). Ethical guidlines for educational research (4th ed.). London: British Educational Research Association.

Bryan, H. (2012). Reconstructing the teacher as a post secular pedagogue: A consideration of the new Teachers' Standards. Journal of Beliefs \& Values, 33(2), 217-228. https://doi.org/10.1080/13617 672.2012.694064.

Bryan, H., \& Revell, L. (2011). Performativity, faith and professional identity: Student religious education teachers and the ambiguities of objectivity. British Journal of Educational Studies, 59(4), 403-419. https://doi.org/10.1080/00071005.2011.602328.

Connelly, M., \& Clandinin, J. (Eds.). (1999). Shaping a professional identity: Stories of education practice. London: Althouse Press.

Cooling, T. (2010). Doing god in education. London: Theos.

Copley, T. (2005). Indoctrination, education and god. Virginia: SPCK Publishing.

Czarniawska, B. (2014). Social science research: From field to desk. London: SAGE.

Estola, E., \& Elbaz-Luwisch, F. (2003). Teaching bodies at work. Journal of Curriculum Studies, 35(6), 697-719. https://doi.org/10.1080/0022027032000129523.

Everington, J. (2012). 'We're all in this together, the kids and me': Beginning teachers' use of their personal life knowledge in the Religious Education classroom. Journal of Beliefs \& Values, 33(3), 343-355. https://doi.org/10.1080/13617672.2012.732815.

Everington, J. (2014). Hindu, Muslim and Sikh religious education teachers' use of personal life knowledge: The relationship between biographies, professional beliefs and practice. British Journal of Religious Education, 36(2), 155-173. https://doi.org/10.1080/01416200.2013.820169.

Everington, J. (2015). Bridging separate communities: The aspirations and experiences of minority ethnic religious education teachers in England. Journal of Beliefs \& Values, 36(2), 165-174. https:// doi.org/10.1080/13617672.2015.1046232.

Everington, J. (2016). 'Being professional': RE teachers' understandings of professionalism 19972014. British Journal of Religious Education, 38(2), 177-188. https://doi.org/10.1080/01416 200.2016.1139892.

Farrell, F. (2016). 'Why all of a sudden do we need to teach fundamental British values?' A critical investigation of religious education student teacher positioning within a policy discourse of discipline and control. Journal of Education for Teaching, 42(3), 280-297. https://doi.org/10.1080/02607 476.2016.1184460.

Franken, L., \& Loobuyck, P. (2017). Neutrality and impartiality in RE: An impossible aim? British Journal of Religious Education, 39(1), 1-6. https://doi.org/10.1080/01416200.2016.1218219.

Gilliat-Ray, S. (2005). Closed worlds: (Not) accessing Deobandi Dar ul-Uloom in Britain. Fieldwork in Religion. https://doi.org/10.1558/firn.v1i1.7.

Gilliat-Ray, S. (2011). 'Being there'the experience of shadowing a British Muslim Hospital chaplain. Qualitative Research, 11(5), 469-486. https://doi.org/10.1177/1468794111413223.

Guenther, K. M. (2009). The politics of names: Rethinking the methodological and ethical significance of naming people, organizations, and places. Qualitative Research, 9(4), 411-421. https://doi. org/10.1177/1468794109337872.

Jackson, R., \& Everington, J. (2017). Teaching inclusive religious education impartially: An English perspective. British Journal of Religious Education, 39(1), 7-24. https://doi.org/10.1080/01416 200.2016.1165184.

Jeldtoft, N. (2016). The hypervisibility of Islam. In N. Dessing, N. Jeldtoft, \& L. Woodhead (Eds.), Everyday lived islam in Europe. London: Routledge.

McDowell, L. (2016). Reflections on research practice: Writing difference. Australian Feminist Studies, 31(89), 355-362. https://doi.org/10.1080/08164649.2016.1254025.

Miller, J., \& McKenna, U. (2011). Religion and religious education: Comparing and contrasting pupils' and teachers' views in an English school. British Journal of Religious Education, 33(2), 173-187. https://doi.org/10.1080/01416200.2011.543599. 
Osler, A. (1997). Education and careers of black teachers. Buckingham: Open University Press.

Religious Education Council. (2013). A review of religious education in England. London: Religious Education Council.

Shah, S. (2016). Education, leadership and Islam: Theories, discourses and practices from an Islamic perspective. London: Routledge.

Shah, S., \& Shaikh, J. (2010). Leadership progression of Muslim male teachers: Interplay of ethnicity, faith and visibility. School Leadership \& Management, 30(1), 19-33. https://doi.org/10.1080/13632 430903509733.

Sikes, P., \& Everington, J. (2003). 'I'm a Woman Before I'm an RE Teacher': Managing religious identity in secondary schools. Gender and Education, 15(4), 393-406. https://doi.org/10.1080/09540 250310001610599.

Sikes, P., \& Everington, J. (2004). 'RE teachers do get drunk you know': Becoming a religious education teacher in the twenty-first century. Teachers and Teaching, 10(1), 21-33. https://doi.org/10.1080/13540 600320000170909.

Spalek, B. (2005). A critical reflection on researching black muslim women's lives post-September 11th. International Journal of Social Research Methodology, 8(5), 405-418. https://doi.org/10.1080/13645 57032000232862.

Vince, M. (2019). I don't necessarily identify myself as a Muslim [RE] teacher?': Considering the limitations of the category 'Muslim' in the case of 'Muslim RE teachers. Journal of Beliefs \& Values. https ://doi.org/10.1080/13617672.2019.1686733.

Publisher's Note Springer Nature remains neutral with regard to jurisdictional claims in published maps and institutional affiliations. 